Вип. 4, 2019

УДК 331

JEL Classification Code M 14

I. Farynovych, Kh. Danylkiv, V. Havran

Lviv Polytechnic National University

\title{
PECULIARITIES OF THE CORPORATE CULTURE DEVELOPMENT AND ITS INFLUENCE ON THE LABOUR ACTIVITY MOTIVATION OF PERSONNEL
}

http://doi.org/10.23939/semi2019.04.129

(C) Farynovych I., Danylkiv Kh., Havran V., 2019

The article summarizes the theoretical ideas of scientists about nature of corporate culture. The main stages of its formation at the enterprise are determined. The importance of corporate culture in the enterprises management is substantiated. The influence of corporate culture on the labour activity motivation of the personnel at enterprises is considered.

Key words: corporate culture, motivation, labour relations, labour activity, personnel, forming and realization of corporate culture

Statement of the problem

In Ukraine labor relations are developed under the influence of social, economic and political factors and are accompanied by personnel's mistrust and uncoordination Such contradictions can be resolved by forming a corporate culture. Scientists state that the concept of "corporate culture" first appeared in the United States of America, while studying the dimensions of the American companies' activities. As the experience of successful foreign companies proves, the corporate culture is a tool for enterprise development by creating trusting, friendly relations between company's managers and employees.

Analysis of recent research and publications

Some aspects of corporate culture, as the analysis shows, were studied by many foreign and domestic scientists. The problems of formation and development of corporate culture have received considerable attention in the works of such scholars as: G. Zakharchyn, L. Volyanska-Savchuk, I. Novak, O. Androsova, T. Belyak, O. Dyakiv, O. Balyka, G. Kopets, N. Smolinska and others. However, despite the high scientific interest in this topic, it should be noted that it is not enough investigated.

The formulation of objectives

The aim of the article is to study the impact of corporate culture on the labour activity motivation of enterprises personnel. In order to achieve this aim, the following tasks are set:

- to consider the nature of the concept of corporate culture;

- to investigate stages of formation and development of corporate culture;

- to identify the role of corporate culture in personnel motivation and enterprise development.

\section{Presentation of main materials}

As the global experience of successful companies shows the introduction and development of corporate culture is a necessary component of the effective functioning of any business entity. Corporate culture should promote harmonious labour relationships and meet the demands of the times.

Corporate culture refers to significant assumptions that are considered by enerprise members as an axiom and are manifested in certain values that set employees directions in their behaviour [1].

Volyanska-Savchuk L.V. interprets the term corporate culture as "a specific, for a given enterprise, organization, firm, dynamic system of formal and informal rules, norms, values, customs and traditions, 


\section{Farynovych, Kh. Danylkiv, V. Havran}

individual and group interests in their integrity and indissoluble unity, which are perceived by most of the personnel, and set a vector of their labour behaviour for the successful performance of a corporate mission" [2].

T. O. Belyak regards corporate culture as a system of three interrelated concepts [3]:

- it is a system of significant values that are determined through the formation of the mission and strategy of the enterprise;

- it is a mechanism of application of enterprise values within professional activities;

- it is a system of values, which are respected by the enterprise managers and employees through established standards of behaviour.

O. P. Dyakiv [4] gives such definition of the corporate culture "it is a system of interacting material and spiritual values and manifestations, inherent in a given company, reflecting its individuality and percepting itself and others in the social and material environment, that appears in the behaviour and interaction, perception of itself and the environment".

O. G. Balyka believes that corporate culture should be considered as a set of ideas approved in the organization, priorities, norms and rules of staff behaviour, customs and thinking that are formed in the process of joint activities in order to achieve the overall purpose of the separate organization [5].

Forming an effective corporate culture of the company and its influence on the personnel motivation, it is necessary to apply a corporate culture of a progressive type, which is based on compliance of labour values and creating a harmonious atmosphere and responsibility for the acivity results.

The corporate culture formation based on strategic management, organizational behaviour theory and organization has begun in the United States of America since the 1980s.

Moltke was the first who applied the concept of corporate culture that characterized the relationship in the officer environment. In the XIX century, representatives of the School of Human Relations began to study the influence of employee relations on its development. Using the Hawthorne experiment cunducted in the 1930s in the Chicago company, it was concluded about the need for understanding by individual employee in the organization and development of group unity on the basis of shared values [6, p. 87].

In the 1930s, in Japan, the idea of ethical and moral rules of employee behaviour in the company emerged in business circles, which was due to the improvement of enterprise management efficiency. Subsequently, the idea of business development based on the culture of the organization was borrowed by Americans. Since the second half of the twentieth century, the concept of "corporate culture" has began to be formed by including joined spiritual and material values of employees' lives.

L. V. Volyanska-Savchuk [2] has systematized in her research works the stages of formation and development of corporate culture and defined its role in the activity of enterprises at each stage.

The first stage of corporate culture the formation was from the end of the XIX century to the middle of the XX century. This stage is based on production technology. The formation of an atmosphere at the enterprise, which could help to increase labour productivity, is in the background. The methods of forming the culture of the enterprise are superficial and formalized. The main role of culture in the enterprise is to form a family atmosphere, to harmonize relations between employees. Autocratic culture is developing at this stage.

The second stage of corporate culture formation and development is oriented to the standards of management and was developing from the middle to the end of the XX century. The formation of enterprise culture is based on standardized methods. Enterprise culture plays an important role in creating value system and guidances for employees. This stage of corporate culture development has been represented by bureaucratic culture.

The third stage of corporate culture development is since the end of XX century - beginning of XXI century. It is oriented on creative. Corporate culture is based on the common values and mutual interests of company employees. A key method of forming a corporate culture is the process of joint activity and interaction between personnel. The role of corporate culture is crucial for the development of companies, because the culture of the company is the key to a successful business operation that can unite the creative team to achieve the corporate mission. Such kind of culture as innovative is developing at this stage.

The corporate culture formation and development is purposeful and must respond effectively to various situations, including spontaneous ones. The culture of the enterprise should influence the strengthening of the collective spirit of personnel. The main principles of the developed corporate culture 
of the enterprise should ensure successful result of its activities by loyal relationships between employees with an individual approach to any person in the company [7].

According to Dyakiv O.P., during the creation of corporate culture, the management of the enterprise should go through the following main stages [4]:

- defining the enterprise's mission, strategy, key goals and values;

- studying the current corporate culture at the enterprise. Substantiating correspondence of the current corporate culture with the strategy of company development, determination of values formed at the enterprise;

- working out organizational measures aimed at developing and affirming the necessary values and style of behaviour;

- studying impact of negative values and own guidelines formation and development on the corporate culture that will contribute to the implementation of the developed enterprise strategy;

- assessing the success of influences on corporate culture with making necessary adjustments.

I. M. Novak suggests such sources of corporate culture as: a system of individual values and methods of their realization; ways, principles of arranging enterprise's activity and structure; a vision of the optimal and acceptable model of personnel's behaviour in the company. The mechanism of corporate culture formation and development is an interactin of the above-mentioned sources that form values hierarchy. The hierarchical system of grouped values forms the most acceptable set of means of their implementation, which are introduced into enterprises' activities thereby forming group styles of behaviour [8].

In Ukraine, corporate culture begins its implementation process in the economy of the country due to the socio-economic transformation and carrying out a number of reforms [9].

Company's corporate culture is formed and developed under the influence of both external and internal factors. The corporate culture formation under the influence of external factors deals with the longterm strategy of the enterprise, which results in the selection of optimal requirements and rules developed by the executives and the team. The corporate culture formation under the influence of internal factors deals with the system of priority values, mission and ways of their achievement [8].

L. V. Volyanska-Savchuk [2] grouped in her scientific work the following factors of influencing the corporate culture formation and development in terms of external and internal environment. The author concluded that external factors influence more on the corporate culture formation and development than internal ones (Table).

External and internal factors of influence on the corporate culture formation and implementation [2].

\begin{tabular}{|c|}
\hline Internal factors of influencig the corporate culture formation and implementation \\
\hline Individualism of the personnel \\
\hline Subcultures of subdivisions and their functions \\
\hline Organizational behaviour the personnel \\
\hline Priority of external or internal goals of the enterprise \\
\hline Degree of adherence to strategic and operational plans \\
\hline Advantage of group or individual decision-making forms \\
\hline Complexity and formalization of corporate culture \\
\hline Co-operation or competition between members of small groups \\
\hline Awareness of corporation members in their roles \\
\hline Social orientation of corporate culture \\
\hline Dedication and loyalty to the company \\
\hline Integration factor of enterprise members \\
\hline Corporate mission, goals, strategy, norms, values, style, spirit \\
\hline Motivation and attitude to work \\
\hline Axternal factors influencing the corporate culture formation and implementation \\
\hline Metide to risk, innovation, progress or stability \\
\hline Personnel management technology and nature of enterprise activity \\
\hline
\end{tabular}

An effectively formed corporate culture is an effective tool for influencing staff motivation. The corporate culture creates a friendly atmosphere in the enterprise. A well-established relationships within the company is an integral part of a developed business. 
The components of corporate culture, such as goals, mission of the company, behavioural styles, corporation values, principles of doing business, have influence on stimulating employees' intangible motivation. If in the company employees and executives have the same viewpoints on corporate culture, then corporate culture plays a motivation role for employees. Corporate culture as a lever to influence the motivation of employees' work promotes selflessness. As motivated workers are more energetic, they selflessly perform their tasks and work productively.

The main directions of influence of corporate culture on the motivation of employees' work are: a friendly atmosphere in the team, support for staff development (professional development, internships, participation in grants, etc.), responsibility of administrative personnel and employees for the main goals of company development, motivation of employees through tangible and intangible incentives, initiative, creativity and innovation. According to the world leading companies experience, the main incentive to retain experienced employees in the enterprise is to emphasize their importance in the team, to respect their work and to encourage them with social benefits, etc. Small businesses should strive to create a friendly atmosphere where individualism and initiative of the individual employee with his/her career promotion are highly valued. Studies show that only $20 \%$ of employees change their jobs because of low wages [10]

The role of corporate culture in the personnel motivational activity (Fig.).

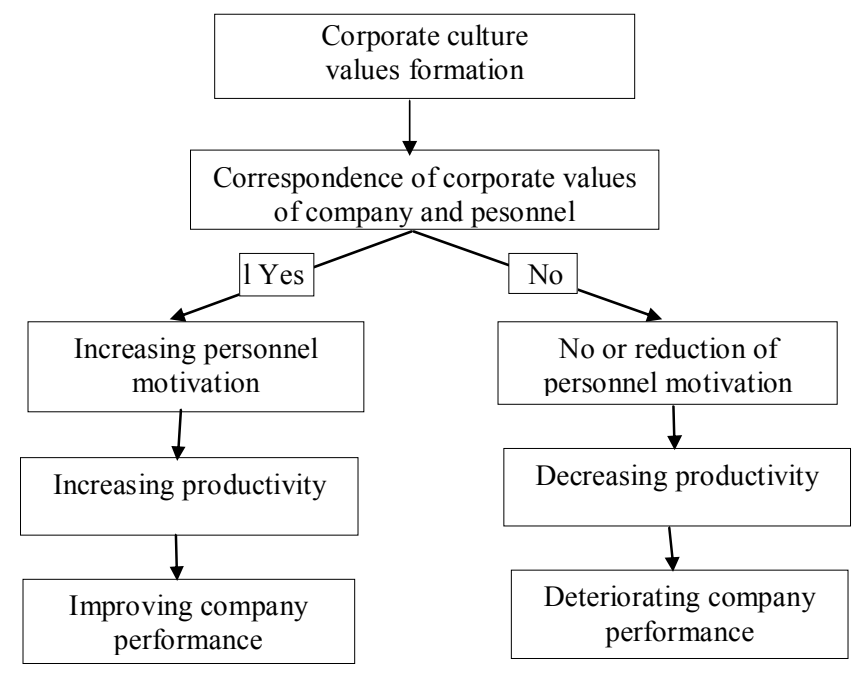

The role of corporate culture in the motivational activity of enterprises Source: performed by the authors

According to Martyn Potter, those firms that want to reduce staff turnover should focus on the intangible motivation of employees, rewarding creative and the most initiative employees. More than $70 \%$ of large corporations believe that employers should participate in the retirement savings of employees. Another component of personnel motivating incentives is the reimbursement of employees' transportation costs or the use of official vehicles [10].

The integration of corporate culture with the labour relations system is an innovative idea because the developed and implemented corporate culture is a stimulant for business entities' activities.

Thomas J. Peters and Robert X. Waterman's research based on leading companies in the United States, as well as domestic sociologists' research works show that $88 \%$ of the companies have certain units responsible for the formation and development of corporate culture; $65 \%$ of companies use programs that provide combination of the corporation ethical and moral values with profitability measures; $58 \%$ of companies independently developed their own corporate culture programs adapted to their own business strategy and applied them in their activities [6].

The conducted domestic sociological studies on the development and implementation of corporate culture programs in Ukrainian companies have shown the following data: $55 \%$ of domestic executives of firms believe that corporate culture should be ideal; $40 \%$ of Ukrainian entrepreneurs are eager to develop a corporate culture focused on European technologies; $35 \%$ of managers of Ukrainian companies believe that corporate culture should be in the enterprise, but for its formation there is neither time nor resources, and $25 \%$ of the business entities management believe that corporate culture is not needed [6]. 
The experience of successful companies proves that the corporate culture formation and development is a significant task that contributes to their development. Firms such as Hewlett Packard, Sony and Motorola adhere to unchanged core values, even when adjusting business strategy.

As R. Hashimoto stated, one can force to work, but one cannot force to think. Therefore, in order to increase personnel productivity, it is necessary to create such conditions that would encourage labour efficiency [3].

Corporate culture is a tool in enterprise management and is a componential part of the cultural environment of society. Enterprise culture is a psychological incentive that promotes business growth.

\section{Conclusions}

Thus, corporate culture is an object of administrative management that plays an important role in its system. A formed strong corporate culture should be based on ethical and moral values of doing business processes, which is aimed on taking care of the personnel. An effective corporate culture is embodied by top-level executives in order to gain team collaboration and achieve enterprise prosperity.

A productive corporate culture enables companies to reduce costs by reducing staff turnover and increasing employees' productivity level and consequently achieve a higher level of competitiveness.

Therefore, the formation of the company corporate culture should be based on international standards, as well as on the company development strategy that will allow to create such labour conditions in which employees wll be motivated and will work with higher productivity.

\section{Prospects for further research}

The substantiated theoretical foundations of corporate culture formation and its role in employees' motivation will be applied in further studies to evaluate the impact of corporate culture on the motivational components of personnel activities.

1. Захарчин Г. М. , Любомудрова Н. П., Винничук Р. О. (2015). Мотивування й розвиток персоналу: культурологічний аспект: моногр. / Г. М. Захарчин. Львів: Видавництво Львівської політехніки, 284 с.

2. Волянська-Савчук Л. В. (2017). Формування та розвиток корпоративної культури на підприємствах машинобудування [текст] : дис. к.-та екон. наук : 08.00 .04 / Волянська-Савчук Леся Вікторівна, Хмельницький. с. 256.

3. Беляк Т. О. (2016). Активізація впливу корпоративної культури на розвиток соціально-трудових відносин [текст] : дис. к.-та екон. наук : 08.00.07 / Беляк Тетяна Олексіївна, Кіровоград. с. 269.

4. Дяків О. П. (2010). Основні складові формування корпоративної культури в організації, Формування ринкової економіки : зб. наук. праць. Соціально-трудові відносини: теорія і практика. К.: КНЕУ, Т. 3. С. 94-100.

5. Балика О. Г. (2005). Стратегічне спрямування корпоративної культури підприємства Available at : https://core.ac.uk/download/pdf/32606967.pdf.

6. Савчук Л. (2005). Розвиток корпоративної культури в Україні, Персонал. К., № 5. С. 86-89.

7. Гриценко Н. В. (2017). Особливості формування корпоративної культури організації , Вісник економіки транспорту і промисловості. Соціально-економічні питання. № 59. - С. 284-290.

8. Новак I. М. Формування корпоративної культури та їі місце в системі соціального діалогу, IDCD. Соціальний захист. с. 104-112.

9. Андросова О. Ф. (2017). Визначення і сутність корпоративної культури в сучасному управлінні, Придніпровська державна академія будівництва та архітектури. Східна Європа: економіка, бізнес та управління. Випуск 6 (11). С. 224-233.

10. Копець Г. Р. Роль корпоративної культури у мотивації персоналу Available at: Lviv Polytechnic National University Institutional Repository http://ena.lp.edu.ua.

11. Смолінська Н. В. (2014). Організаційна культура інноваційного розвитку машинобудівних підприємств : автореф. дис. ... канд. екон. наук : 08.00.04 / Н. В. Смолінська; Нац. ун-т “Львів. Політехніка”. Львів, 23 с. укр.

1. Zakharchyn H. M., Liubomudrova N. P., Vynnychuk R. O. (2015). Motyvuvannia y rozvytok personalu: kulturolohichnyi aspekt: [Personnel motivation and development: culturological aspect] monohrafiia: [monograph]. Lviv: Lviv Polytechnic Publishing House, 2015. 284 p.

2. Volianska-Savchuk L. V. (2017) Formuvannia ta rozvytok korporatyvnoi kultury na pidpryiemstvakh mashynobuduvannia [Formation and development of corporate culture at the mechanical engineering enterprises] (PhD Thesis), Khmelnytskyi, p. 256. 
3. Beliak T. O. (2016). Aktyvizatsiia vplyvu korporatyvnoi kultury na rozvytok sotsialno-trudovykh vidnosyn [Activation of the influence of corporate culture on the development of social and labour relations] (PhD Thesis), Kirovohrad, p. 269.

4. Diakiv O. P. (2010). Osnovni skladovi formuvannia korporatyvnoi kultury v orhanizatsii [The main components of the formation of corporate culture in the organization]. Formuvannia rynkovoi ekonomiky [Market Economy Formation]: scientific journal, Sotsialno-trudovi vidnosyny: teoriia i praktyka [Social and Labor Relations: Theory and Practice], 3. K.: KNEU, 94-100.

5. Balyka O. H. Stratehichne spriamuvannia korporatyvnoi kultury pidpryiemstva [Strategic direction of enterprise corporate culture]. Retrieved from https://core.ac.uk/download/pdf/32606967.pdf.

6. Savchuk L., Burlakova A. (2005). Rozvytok korporatyvnoi kultury v Ukraini [The developmet of corporate culture in Ukraine]. Personal [Personnel], 5, 86-89.

7. Hrytsenko N. V. (2017). Osoblyvosti formuvannia korporatyvnoi kultury orhanizatsii [Peculiarities of enterprise corporate culture formation]. Visnyk ekonomiky transportu i promyslovosti. Sotsialno-ekonomichni pytannia [Bulletin of Transport and Industry Economics. Socio-Economic Issues], 59, 284-290.

8. Novak I. M. Formuvannia korporatyvnoi kultury ta yii mistse v systemi sotsialnoho dialohu [Formation of corporate culture and its place in the social dialogue system]. IDCD. Sotsialnyi zakhyst [Social Protection], $104-112$.

9. Androsova O. F. (2017). Vyznachennia i sutnist korporatyvnoi kultury v suchasnomu upravlinni [Definition and nature of corporate culture in modern management]. Skhidna Yevropa: ekonomika, biznes ta upravlinnia [Eastern Europe: Economics, Business and Management], 6 (11), 224-233.

10. Kopets H. R., Leskiv M. R. Rol korporatyvnoi kultury u motyvatsii personal [The role of corporate culture in personnel mitivation]. Retrieved from Lviv Polytechnic National University Institutional Repository http://ena.lp.edu.ua.

11. Smolinska N. V. (2014). Orhanizatsiina kultura innovatsiinoho rozvytku mashynobudivnykh pidpryiemstv [Organizational culture of innovative development of machine-building enterprises] (Abstract of PhD Thesis), 23.

І. В. Фаринович, Х. П. Данилків, В. Я. Гавран Національний університет "Львівська політехніка"

\section{ОСОБЛИВОСТІ РОЗВИТКУ КОРПОРАТИВНОЇ КУЛЬТУРИ ТА ЇЇ ВПЛИВ НА МОТИВАЦЮЮ ТРУДОВОЇ ДІЯЛЬНОСТІ ПЕРСОНАЛУ}

(C) Фаринович I. В., Данилків Х. П., Гавран В. Я., 2019

Узагальнено теоретичні уявлення науковців про сутність корпоративної культури. Визначено основні етапи їі формування на підприсмстві. Обгрунтовано значимість корпоративної культури в управлінській діяльності підприсмств. Розглянуто вплив корпоративної культури на мотивацію трудової діяльності персоналу підприємств.

Для сучасного суспільства, що розвивається в мінливих умовах, актуальним с пошук дієвих методів управлінського впливу на персонал. Одним із важливих інструментів такого впливу с формування та розвиток корпоративної культури, про що свідчать успіхи компаній різних країн світу, які декларують основні норми, засади та правила корпоративної культури, визнаючи їі провідним чинником розвитку та конкурентоспроможності суб'скта господарювання. Роль чинника корпоративної культури в соціальній системі стас визначальною, коли виникає необхідність формування нової стратегії й моделі бізнесу та побудови на їх основі нової системи цінностей. Незважаючи на досить значну кількість зарубіжних і вітчизняних публікацій, можемо стверджувати, що сдиного погляду на поняття, термінологію й методологію цісї тематики ще не сформовано. Найбільшу складність зумовлюс створення практичного інструментарію формування та розвитку корпоративної культури. Визначаючи характер людських взаємодій, корпоративна культура стає необхідно передумовою формування ефективного управління персоналом суб'скта господарювання. Корпоративна культура як важіль впливу на мотиваційну діяльність працівників заслуговує особливої уваги. Однак їі реалізація залежить від усіх суб'сктів корпоративної культури, а саме керівників компанії, HR-менеджера, a також працівників. Основні напрями впливу корпоративної культури на мотивацію трудової діяльності працівників: доброзичлива атмосфера в колективі, підтримка розвитку персоналу (підвищення кваліфікації, стажування, участь у грантах та ін.), відповідальність адміністративного персоналу та працівників за основні цілі розвитку компанії, заохочення працівників через матеріальні та нематеріальні стимули, ініціативність, креативність та новаторство. Підвищення мотивації працівників впливає на зростання продуктивності праці, що своєю чергою підвищус рівень результативності діяльності компанії.

Ключові слова: корпоративна культура, мотивація, трудові відносини, трудова діяльність, персонал, формування та реалізація корпоративної культури. 